\title{
The Representation of Ethnic Diversity in the Southeast Sulawesi in the Collected Poems "Kesaksian Bumi Anoa"
}

\author{
Rasiah $^{1}$, Arman $^{2}$, Rahmat Sewa Suraya ${ }^{3}$, Ela Martisa ${ }^{4}$, Wa Ode Halfian ${ }^{5}$, La Bilu ${ }^{6}$ \\ \{rasiahfib@uho.ac.id ${ }^{1}$,arman@gmail.com ${ }^{2}$, sewa.suraya@gmail.com ${ }^{3}$, ela.martisa@gmail.com ${ }^{4}$, \\ ode.wa@gmail.com ${ }^{5}$, la.bilu@gmail.co ${ }^{6}$ \} \\ ${ }^{123456}$ Universitas Halu Oleo Kendari, Sulawesi Tenggara, Indonesia
}

\begin{abstract}
Diversity is an inevitable fact that exist in Indonesia's society. It then uses to become a pride instead of the problems in Indonesia's societal life. Literary works documented the ethnics' otherness either to persuade readers to maintain the diversity to raise a mutual respect and tolerance towards differences and similarities in life, or to construct the identity to resist or to sustain racism. Kesaksian Bumi Anoa is one of the literary works that expose the ethnic diversity in the Southeast Sulawesi as one province in Indonesia. It is a collected poems consisted of five poems written by local writers and published in 2018. The study incorporated representation theory and semiotic analysis. It found that each piece of the collected poems reflected the ethnic identity in the Southeast Sulawesi through the the specific cultural symbols and problematic life perceived by the fiction-characters displayed in the poems.It depicted Muna, Buton, Bajau, and Moronene's ethnic identities. Those are pictured through the excerpt of history, social system, local language, and local wisdoms that enable us to see and understand the philosophy of their lifes and differences and similarities among them. These poems have been a document that displayed the sprit of the given era.
\end{abstract}

Keywords—Diversity, ethnic, identity, local literature, representation

\section{Introduction}

Literature that was born in a community will, in many ways, reflect the state of social and cultural life of the community. It is because literary works are not born in a cultural vacuum, but they obtain cultural forms of a society such as cultural traditions, customs, conventions, beliefs, ways of life, ways of life, ways of thinking, views about aesthetics [1]. Literature then can be seen as an integral part of the socio-cultural life of the people who gave birth to it. Although this may not be justified at all in recent social life, the situation seems to be dominant in marking people's lives at specific time. Beforehand, Plato [2] argued that literary work is an artificial world, for what is reflected in it is the result of imitation of the real world and human life. Though Plato doubted the perfection of the imitation, he required that a good literary work is "must describe the truth" [2]. Plato's views then gave birth a literary criticism that 
emphasized literature through mimetic approach, that is literature is the reflection of social reality [3]. By this perspective, literature can be a document to search the social condition of particular people and era.

Many scholars justified that literary work is documenting the socio-cultural life of the community. Valdes identifed the values of American culture through literary works [4]. Let say, the problem of freedom, for example, can be found in Mark Twain's Huckleberry Finn novel. Valdes [4] stated the issue of uniqueness as a strong concept in American culture and competitive attitude and fair play have become a part of life, especially in the field of sports, that can be seen in Stephen Crane's The Bride Comes to Yellow Sky, George Summer Alhee's The Top, and Edith Wharton's Roman Fever. Rasiah [5] used Charlotte Bronte's Jane Eyre to depict the struggle for women equality in era of Victoria in England. The way of Jane Eyre seeked to exist in the reflection of woman struggle to exist at the time. Even the presents century, the problem of racism in the United States still can be also traced through slavery themed novels that appeared in the twenty first century [5]. In Indonesian context, novel like Pengakuan Pariyem, Ronggeng Dukuh Paruk, Burung-Burung Manyar also documented so well about the life and cultural attributes of Indonesian, especially Javanese social and cultural attributes [1]. This will be more clearly seen in works because they are carrying a typical social setting. Kesaksian Bumi Anoa [6] is a collected poem that has a typical setting and emphasizes the specific nature of the particular setting. It exposes about the problematic life of people in the regions of Southeast Sulawesi; Muna, Buton, Bombana-Kabaena, and Bajau. It is consisted of five poems and published in 2018 by Cerah Budaya Indonesia Publisher. Every single background of people that exposed in the poems has a specific cultural identity that has become the core of people composition in the Southeast Sulawesi. The acquaintance of those ethnic attributes could be indirectly sharing and preserving the diversity for generation and/or for the others through literary works.

Few scholars have also discussed about the poems. However, they discussed different segments. Let say, [7] discussed the poem by exposing the marginality and powers in the Southeast Sulawesi, [6] talked about the difficulty of people life in Southeast Sulawesi, Ramis [8] discussed about the poems as through Allan Badiou perspective about author subjectivation as the truth procedure, and Ratih Dede [9] is taking about a single poem entitled Puncak Rindu Sabhampolulu to talk about the social life of Mornene's people in the Southeast Sulawesi. From those discussions, it is seen that the discusion about representation of ethnic identity is not elaborated yet.

These poems actually classified as essay poetic that considered as a new form of poetry that appeared in the contemporary Indonesian Literature [5]. Pioneered by Denny J A [10], essay poetic of Kesaksian Bumi Anoa composed the poems by intersecting the imaginary and real facts that happened in the South East Sulawesi to depict its inner and social issues. From that such composition, the poems are intended to expose and disapprove the socio-cultural problems that occurred in those specific regions. In addition the readers, as Denny JA [10] points out, do not only able to capture the inner side of individuals, but also the social conflicts that exist and occur in the society through fiction. Thus, essay poetic of Kesaksian Bumi Anoa presents a social fact portrayed by the poets as mental evidence that does not appear in social or historical writings (non-fiction). From the above background, this paper is intended to show how ethnic diversities in the Southeast Sulawesi displayed in the collected poems Kesaksian Bumi Anoa.

Theory that used in this paper to elaborate the ethnic identity in Kesaksian Bumi Anoa is representation theory proposed by Stuart Hall [11] incorporated with semiotic analysis. According to Hall [11] representation is an essential part of the process by which meaning is produced and exchanged between members of a culture, that is the use of language, of signs, 
and images which stand for or represent things. Hall [11] described two processes or two systems of representation. The first is the system that is making the concepts or mental representations of objects, people, or event which we carry around in our heads. Without this concept, we could not interpret the world meaningfully at all. The second is the language itself. The general term we use for words, sounds, or images which carry meaning is sign. Those signs stand and represent the concepts and the conceptual relations between them which is carry around in our head together and they make up the meaning-systems of our culture. Signs are organized into language and it is the existence of common languages which enable us to translate out thoughts or the concepts in our mind into the words, sounds or images. It is operating as a language, to express meanings and communicate thoughts to other people.

\section{Result And Discussion}

Bumi Anoa in this poem refers to Southeast Sulawesi itself. Anoa is an endangered animal which resembles a goat or cow living in the hinterland of southeast Sulawesi and it used to become an emblem of the Southeast Sulawesi. The collected poem hooked up this symbol to reveal that these poems revealed about in the Southeast Sulawesi. It is covering about Buton, Muna, Bajau, and Mornene's ethnic lifes.

A. Depiction of Butonese ethnic identity

Kesaksian di Negeri Butuni by La Ode Gusman Nasiru portrays Butonese ethnic identity through the love story of Wa Ode Widarni and Hamid. It presents the love story of two people who are constrained by social status. The aspect of locality of Buton is so strongly expressed in this poem through language and cultural codes, exotic nature and the historical fame land sweetened with global aspects that become 'enhancers' of the aesthetic value of this poem. The insertion of French words makes this poem looks special because it is able to link local and global aspects as part of a plot that reinforces multiculturalism aspects. Let's consider the following piece of the poem.

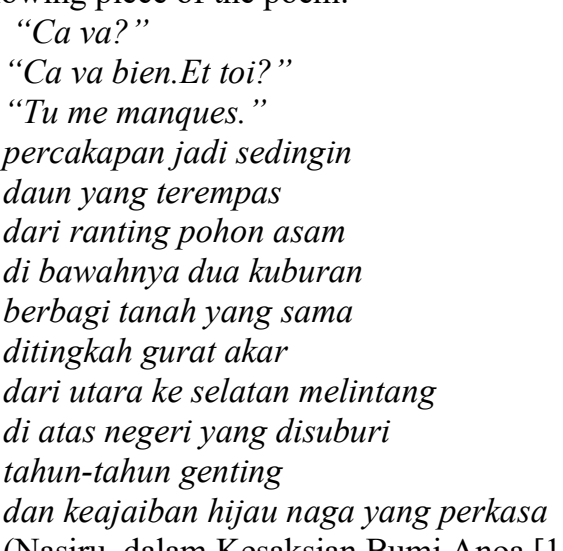

(Nasiru, dalam Kesaksian Bumi Anoa [12])

The representation of ethnic Buton identity in the fragment of the poem above appears firstly and mainly in the symbol of a dragon. Dragon in the language of the Wolio called Lawero is a symbol of strength and firmness of principles that cannot be influenced by anyone [13]. According to local legend, this statue has existed since the days of the Buton sultanate. It is said that there was an admiral from the Mongols who lost the war in Java, then went to Buton 
Island, so this dragon and tail statue is a symbol of the existence of the Chinese on the island of Buton. Even this dragon also shows the economy of the Sultanate of Buton with the Chinese empire in the kingdom's era [14]. The dragon statue is green and has now become a cool icon to attract tourists on the island of Buton. Its existence is also interesting because the body of the dragon statue is located in two different places. The dragon's head is on Kamali beach, while the tail is in front of the mayor's office. The head is quite high about 5 meters and he posed by showing off his claws. Meanwhile, as far as five $\mathrm{km}$ from the dragon body statue, there is a dragon tail statue which is now in front of the Buton Mayor's office. About 7 meters high in very unique shape.

Other identities in this poem can be seen in the mention of the Citadel and historical figures of the ancient kings of Buton. Such are Mr. Dungkucangia and Sultan Gafurul Wadudu. These two figures are closely related to the history of the land of Buton, namely Dungkucangia is said to be the foundation of the construction of the fort since 1309. Construction was then completed by Sultan Gafurul Wadudu in the midst of the famine and poverty of the people, which became the basis of the impeachment efforts by some people who disagree with it. However, he remained in his post until the construction was completed. When construction was finished, he asked himself to step down as sultan. Meanwhile the people reluctantly asked him to remain the sultan, because the benefits of building the fort were very positive for the survival of the whole community. [12], [15]. Furthermore, M Final Daeng and Nasrullah Nara [15] said that the Wolio Palace Fortress has become a symbol of the glory of the maritime kingdom in the past.

The title of the name 'Ode' that signifies social class also reflected Buton's identity. The fictional characters Wa Ode Widarni and Hamid represent different classes in Butonese societal class. The title 'ode' in the mind of the Butonese is not only reflecting a social status, but rather a prestige that is seen by some as complicating social activities, especially when they are arranging marriage affairs. Oddly enough, the complexity of the social class occurs among these butonese contemporaries, and apparently does not apply to strangers. Nasiru presented the character Ode in his poem and actually married a Frenchman. This reinforces that this poem does not only question the social polemic strata but also capitalism. Capital owners remain number one who wins a fight [7]. The same stories are also raised in many other literary works, such as novel Di Bawah Bayang Bayang Ode.

\section{B. Depiction of Bajau Ethnic Identity}

Manusia Sama di Laut Buton, written by Uniawati, tells the problem that occurred in the Bajau community over the "civilizing" project undertaken by the government. Uniawati presented the Bajau conscience faced with "civilization" projects following the ethics of superiority carried out by the owner of cultural power [5]. Through this poetic expression, we can understand the ethnic identity of the Bajau tribe, often categorized as primitive, illiterate societies, so that their ethnic identity is threatened by acculturation and assimilation projects to reach "ideal culture" in the view of modern mainstream.

The term "manusia Sama" as written by the author in the title of the poem refers to the identity of the Bajau people. According to [16] Bajau people call themselves the "sama people" (Sammal, Sammah) which means tribe or ethnic. While Bajau is a term that comes from people outside the Bajau tribe. Other terms that are often referred to by the Bajau tribe are Sea Peoples, Sea Nomads, Sea Gypsies, Boat Nomads, Nomadic Boat Peoples and so on [17]. Manusia Sama di Laut Buton means the Bajau people who live in the sea of Buton, Southeast Sulawesi. Let's look at the excerpt of the poem.

Manusia Sama di Laut Buton

$/ 1 /$

Sosok lelaki berkulit legam 
terpaku pada sisi karang yang lain

Membiarkan sepasang kaki telanjangnya

bersetubuh dengan asin air

Sementara tatap sepasang matanya jauh

menembus batas cakrawala

Mencari celah pelepas

atas gundah yang mengakrabinya

Mengapa dilema ini ditimpakan padaku, Tuhan?

Engkau telah menciptakan kami turun-temurun

Untuk mengarungi takdir-Mu di atas buih ombak

Melanglang di atas bido bersama restu sang Mbu

Sosok lelaki berkulit legam makin tepekur

The quote indicates that the Bajau ethnic is people who not only has a place to live in the sea, but has a soul that united with the sea. The marine environment has given birth to a unique culture that goes in line with the wisdom of living in the sea. The text above confirms that since its birth, the Bajau people are accustomed to living with the natural sea, achieving freedom in the union of the natural sea. Bido in the poem above refers to the name of the Bajau traditional boat as a means of sea transportation for Bajau people in making a living, as well as a place where they live as a family. However, in the current decade, especially in Southeast Sulawesi, Bajau families are not found living on boats. They already have permanent residences near the sea, but the tradition of being sea people is still maintained, one of them is spirituality aspect as displayed in the following quote.

$[\ldots]$

Di tengah gejolak orang-orang perahu

yang tergiur oleh kepayang

Mengabaikan sumpah para leluhur di bawah ula-ula4

Entah karena alpa atau karena lelah pada nasib

Memutuskan hijrah atas nama keteraturan

Begitulah kabar yang menyentuh dinding pendengarannya

......

Terngiang kembali petuah kakek pada suatu senja

Kala itu mereka sedang duduk di atas bido,

berayun dalam candaan ombak

Mengikuti ritme alam yang tercipta

dalam keajaiban sang Pencipta

Sepasang tangan mengendalikan

gagang kail yang ujungnya menanti mangsa

Larik-larik mantra pun meniti

di atas gagang kail menembus dasar samudra

Memanggil, membujuk, dan merayu

Hingga berbagai jenis ikan berebut

mempersembahkan diri

pada si pemilik lisan bertuah

(Uniawati, dalam Kesaksian Bumi Anoa [18])

Ula-Ula is a special flag that identifies the Bajau tribe. According to Syukur [19] this flag was also called Maulus in local langauge which was hoisted during sailing and when there were community rituals such as marriages and other traditional parties. The above quotation also 
confirms the Bajau tribal belief system. Syukur [19] says that the Bajau tribe is familiar with some of the customs and habits that govern the group's members. As a marine community, the Bajau have a belief in supernatural things even though they identify themselves as Muslims [20]. They still live in the ancestral dimension. The culture of spells, offerings and beliefs of evil spirits still dominate their lives. The role of the shaman is still very dominant to cure illness and to reject reinforcements or provide knowledge. Bajau people really believe in demons in the surrounding environment. They believe restrictions, such as the prohibition of asking neighbors such as kerosene, salt, water or anything after sunset. The following quote corroborate the Bajau's traditional belief.

Lihatlah riak di permukaan laut

Kadang menjelma menjadi ombak

suatu ketika menjadi gelombang

dan tiba-tiba pula menjadi tsunami

Jika kamu tidak memiliki tiang layar yang kuat

mantra pereda badai Mbu Tambirah

nicaya kamu akan binasa bersama bidomu

$M b u$ 's figure as written in the fragment of poem is believed as Mother is a supernatural being of Bajau people and believed to have power outside. Mbu is believed to be both a protector and a destroyer for seafarers who are at sea. Therefore, Bajau sailors usually do not dare to do something that are considered impolite, such as spitting and dirty words, which can cause disaster for them when they are at sea [18]. It was explained in the poem's footnote that the Bajau people has three women who had power in the sea. The three women are Mbu Tambirah, Mbu Duga, and Mbu Janggo. Among the three women, Mbu Tambira is believed to have the most strength. She is considered the leader of all the mothers in the sea. This Bajau tribal belief system has remained sustainable until now. The nature of isolation possessed by the Bajau tribe from the outside world is believed to be an effort to preserve the custom of the candidate, in addition to the existence of the process of inheriting cultural values from generation to the next generation.

C. Deption of Moronene's Ethnic Idenity

The poem of Puncak Rindu Sabampolulu by Mas Jaya presents a description of Kabaena's land in its human activities. Through the depictions of Masni and Amin's inner conflict as the fictional character in the poem, it reflects the cultural identity of the Mornene ethnic group who living in Kabaena Island. Jaya Wrote in his poem that:

Puncak Rindu Sabampolulu

/1/

Sebelum wangi ore membuat sakau

Para investor dan pejabat negeri ini

Kabaena telah menulis kitabnya

Di lembar cerita nenek moyang

Mengalir turun-temurun serupa Lakambula

Bermuara dari satu generasi ke generasi

Berkisah tentang tanah yang terkutuk

Kisah Sampolulu puncak yang tersibak

Kalah dalam perang antara jin penunggu gunung Kabaena

Tanah nan rupawan

Hutannya elok perawan

Gunungnya tinggi memilari langit

Kebunnya menebar wangi mente 
/2/

Di tanah inilah lelaki bernama Amin

Menemukan rusuknya di dada Masni

Amin ialah petani ulet

Begitu pun Masni

Amin juga menekuni pekerjaan lainnya

sebagai pengumpul hasil kebun mente

Masni pun demikian

Ia penjahit yang handal

[....]

The representation of the Mornene ethnic identity in the poem above can be seen first through the title. Sabhampolulu is the name of the highest mountain in Southeast Sulawesi located on Kabaena Island. Taking the background of the mountain, accompanied by a little history of folklore about the fable of Sabhampolulu [21] certainly has a special intention to confirm about Mornene's life. From the origin the word, sabhampolulu is derived from the word sabha which means torn, and mpolulu is an ax. The combination of these two words becomes the name of a tallest mountain that looks like a torn ax. Sabhapolulu Mount was then associated with a form of defeat of the Jinns' fightings in its legend.

Not many Jaya as the author actually represents the cultural identity of the Mornene tribe in the poem above. He explores more critically the impact of development on environmental damage on Kabaena land as well as economic inequality that occurs in the community. However, the environmental damage depicted in this poem also reveals the habits of the Mornene people in carrying out their daily activities. Sinapoy [22] explains that the Mornene tribe inhabits the protected area of Rawa Aopa Watumohai, which influences their activities and culture. Their activities and lifestyle to connect and maintain their sustainability only use forest resources to fulfill their daily needs. For them, the benefits of the forest for daily life are very real. Forests produce goods needed for various purposes such as building wood and materials for making agricultural equipment, plants in the forest for medicinal herbs, forests also provide a comfortable living environment for the community, and more importantly, provide fertile land for farming. This custom has brought Kabaena into an easy target for entrepreneurs, especially when a gold mine was discovered in the area. The portrait of Masni and Amin's life in the poem composed by Mas Jaya, is a representation of the lifestyle of the Mornene people who rely on natural resources.

D. Depiction of Munanenese Ethnic Identity

The identity of the Muna ethnic group is clearly illustrated in the poem composed by Wa Ode Nur Iman entitled Jejak-Jejak Sunyi di Masjid Muna. Iman o expresses the cultural identity of Muna in a critical way. She brought back the facts that need to be contemplated by the current generation of the noble cultural heritage that began to be ignored by the Muna people who were born in the era of technology with a hedonic life style. Let's look at the poem quote.

Jejak-Jejak Sunyi di Masjid Muna

Sore itu

Aku bersamamu

Setelah melewati jalan panjang dan menjumpai banyak cerita

Tak terkecuali bunga-bunga di simpang-simpang jalan

Aku rindu padamu

Juga segala yang kautanak di dalikamu

(Imam, dalam Kesaksian Bumi Anoa, [23]) 
Muna's cultural identity in the poem above is represented through the language used. It inserts of many local language of Muna in the poem, such as the example "Dalika" which means the Muna kitchen stove made from stone and wood-fueled, Tembaha wula (the month of Ramadan), Haroa (a container filled with food to pray for) whose findings refer to the traditions of people Muna in welcoming the fasting month and Eid al-Fitr [24]. In addition, there is also the title Ode in a series of fictional and historical names mentioned in poetry. Like the culture of Buton, an ode degree in the Muna social system is also a symbol of social class and prestige.

The point of the cultural identity representation is actually centered in the Mosque. Masjid Muna where located Tongkuno area. Tongkuno is considered as a place which assigned the birth of the ancient Kingdom of Muna [25]. Let's consider the following quote.

$$
\text { Dalam kisahnya }
$$

La Ode Kadiri memiliki permaisuri

bernama Wa Ode Wakelu dari Buton

Perkawinan La Ode Kadiri dengan Wa Ode Wakelu

menimbulkan kemarahan pihak Kerajaan Buton

Karena pihak kerajaan ingin menjodohkan La Ode Kadiri dengan Wa Ode Sope

Keinginan Kerajaan Buton adalah sebagai bentuk siasat agar Kerajaan Muna berada di bawah kekuasaan mereka yang pada saat itu Kerajaan Buton bersekongkol dengan Belanda Jelang akhir hidupnya

La Ode Kadiri berpesan kepada anaknya

Agar menikahi Wa Ode Sope29

La Ode Rahman lalu memenuhi wasiat ayahnya

Mempersunting Wa Ode Sope sebagai permaisuri di kerajaan

Suatu hari di masa pemerintahan Raja La Ode Rahman di Abad XVI

Datanglah seorang Arab bernama Syaikh Abdul Wahid atau Syarif Muhammad

yang oleh masyarakat Muna

dikenal dengan sebutan Saidhi Raba (Syaikh Arab)

Ia membawa ajaran Islam

Sang raja dalam hal ini La Ode Rahman bersedia menerima Islam sebagai agama resmi di kerajaan dengan suatu syarat

Syarif Muhammad kemudian menanyakan syarat apa yang harus dipenuhinya

"Saya akan menerima Islam sebagai agama resmi di kerajaan ini dengan syarat permaisuri harus mengandung anak dari saya."

Muna Mosque as the object of discussion in this poem is central to expressing the cultural identity of the Muna, both in terms of religion and political tactics. Through the mosque symbol, this poem succeeded in uncovering the story of Muna as a kingdom, its relationship with Buton, its King, Boundary of its area, and its political strategy. The story of the king in this poem is an illustration of the political tactics of the ancient Muna kingdom through Islam. Muna and Buton are two kingdoms that inhabited the same penninsula; they were often involved in tidal relationships. The emergence of the messenger of the prophet Muhammad from Mecca is a picture of how Islam mediates the relationship of Muna and Buton, as well as how their ties are connected in biological kinship. This assumption is reinforced by the fact that at present the two regions of the community are known as devout Muslims. In addition, the $\mathrm{Gu}$ 
and Mawasangka area is the area of Muna Island which faces the open sea directly, making it easier for pilgrims to stop by compared to the center of the Muna Kingdom which is located in the interior and on the hill. Wa Ode Nur Iman brought up this story to rededicate the Muna mosque as a symbol of the triumph of Muna at the time and to be clashed with the attitude of contemporary society. Muna Kingdom did not have palace, but it does have a mosque. The mosque that today is turned into a tourism site with the attitude of ignorant of the government and also the community, is actually the heart that flows past life. It is a symbol of greatness, power, peace and autonomy at that time up to these days.

\section{Conclusion}

This research concludes that the representation of ethnic diversity in the collected poem entitled Kesaksian Bumi Anoa is revealed through cultural symbols. Anoa is a representation of the Southeast Sulawesi itself, Buton is represented through the symbol of gree dragon that embedded the value of power, Muna is represented through the Masjid that reveals the political deals in the ancient kingdom with the rest of the regions, ideology, and way of life. Mornene is represented through a mount that reveals about the defeating of Kabaena from the capital power of the foreigners, and Bajau represented through bido as the boat and Ula-ula as particular part flag to reveal the particular identity of Bajau community who live in the rest of sea. The authors of the poems utilized the ethnic identity nd their problamtic life to be a capital in their authorship and to develop multicultural landmark in the Southeast Sulawesi through the poems. The authors also make cultural identity as capital in their authorship, by looking more closely at how each ethnic group is struggling with the issue of identity which is threatened at any time due to assimilation or acculturation projects and globalization in the presents decade.

\section{References}

[1] B. Nurgiyantoro, "Sastra Sebagai Pemahaman Antarbudaya," J. Cakrawala Pendidik., vol. 3, pp. $1-16,1995$

[2] T. S. Dorsch, Classical Literary Criticism: Poetics; Ars Poetica; On the Sublime (Classics) by Aristotle, Horace and Longinus (Translated). New York: Penguin Classics, 1965.

[3] M. H. Abrams, The Mirror and the Lamp. London: Oxford University Press, 1979.

[4] J. M. Valdes, "Culture in Literature," in Culture Bond, Bridging the Cultural Gap in Language leaching, Cambridge: Cambridge University Press, 1986, pp. 136-147.

[5] Rasiah, M. Thobroni, A. Budiarti, R. Oerbaningrum, and D. Kristianti, Mengenal Puisi Esai. Jakarta: Cerah Budaya Indonesia, 2018.

[6] W. Nurumi, "Ketika Bumi Anoa Tersayat," in 115 resensi Puisi esai dari Aceh Hingga Papua, Jakarta: Cerah Budaya Indonesia, 2019, pp. 587-597.

[7] L. Andri, "Menggempur Kuasa Di Bumi Anoa," in 115 resensi Puisi esai dari Aceh Hingga Papua, 2019, pp. 60-70.

[8] R. Ramis, "Potret Problematika Hidup Masyarakat Kabaena," in Book of 115 resensi Puisi esai dari Aceh Hingga Papua, Jakarta: Cerah Budaya Indonesia, 2019, pp. 598-601.

[9] M. Jaya, "Puncak Rindu Sabampolulu," in Kesaksian Bumi Anoa: Seri Puisi Esai Indonesia Sulawesi Tenggara, Jakarta: Cerah Budaya Indonesia, 2018, pp. 34-57.

[10] J. A. Denny, "Puisi Esai: Apa dan Mengapa?," in Memotret Batin dan Isu Sosial Melalui Puisi Esai, Jakarta: Inspirasi.co Book Project, 2017. 
[11] S. Hall, "Introduction," in Representation: Cultural Representations and Sygnifying Practices, SAGE Publications, 1997.

[12] G. L. Nasiru, "Kesaksian di Negeri Butuni," in Kesaksian Bumi Anoa: Seri Puisi Esai Indonesia Sulawesi Tenggara, Jakarta: Cerah Budaya Indonesia, 2018, pp. 20-33.

[13] Islahuddin, "Sepasang Naga Jadi Simbol Kekuatan Masyarakat Buton," inilahsutra.com, 2019.

[14] T. Yudvi, "Sejarah Patung Naga yang Jadi Simbol Kota Bau-Bau," okelifestyle.com, 2017. .

[15] M. F. Daeng and N. Nara, "Benteng Wolio dan Kisah Maritim," Kompas.com: Jernih Melihat Dunia, 2011. .

[16] F. R. Zacot, Orang Bajo, Suku Pengembara Laut, Terjemahan Fida Muljono dan Ida Budi Pranoto. Jakarta: Gramedia Pustaka Utama, 2008.

[17] R. Indrawasih and I. G. P. Antariksa, "Budaya Bajau: Pemanfaatan Dan Pelestarian Lingkungan," J. Masy. dan Budaya, vol. 5, no. 2, pp. 59-75, 2003.

[18] Uniawati, "Manusia Sama di Laut Buton," in Kesaksian Bumi Anoa: Seri Puisi Esai Indonesia Sulawesi Tenggara, Jakarta: Cerah Budaya Indonesia, 2018, pp. 58-77.

[19] S. Muhammad, "Sistem Sosial dan Kepercayaan Suku Bajo," Attoriolong, vol. 4, no. 1, pp. 8896, 2007.

[20] B. Baskara, "Manifestasi Identitas Islam Suku Bajo Dalam Naskah Lontarak Assalenna Bajo," Kawistara J. Sos. Ilm. dan humaniaora, vol. 1, no. 1, pp. 15-27, 2011.

[21] L. O. Sidu, Cerita Rakyat Sulawesi Tenggara. Jakarta: Grasindo, 2001.

[22] M. S. Sinapoy, "Kearifan Lokal Masyarakat Adat Suku Moronene dalam Perlindungan dan Pengelolaan Lingkungan Hidup," Halu Oleo Law Rev., vol. 2, no. 2, pp. 513-542, 2018.

[23] W. N. Iman, "Jejak Sunyi di Masjid Muna," in Kesaksian Bumi Anoa: Seri Puisi Esai Indonesia Sulawesi Tenggara, Jakarta: Cerah Budaya Indonesia, 2018, pp. 78-91.

[24] R. S. Suraya, "Tradisi Haroa Pada Etnik Muna : Fenomena Budaya Dalam Kehidupan Beragama Di Era GlobaL," E-Jurnal Kaji. Budaya (Online J. Cult. Stud., vol. 10, no. 20, 2014.

[25] J. Couvreur, Sejarah Kebudayaan Muna. Edisi 2. (Translation). Kupang: Arta Wacana Press, 2001. 